\title{
Archaeological research on Rapa Island, French Polynesia
}

\author{
Atholl Anderson \\ Department of Archaeology and Natural History, Research School of Asian and Pacific Studies, The Australian \\ National University, Canberra, Australia, atholl.anderson@anu.edu.au \\ Douglas J. Kennett \\ Department of Anthropology, The Pennsylvania State University \\ Eric Conte \\ Université du Polynésie Française
}

\section{Introduction}

This volume describes the results of archaeological and related research on Rapa Island, which lies at the southern extremity of French Polynesia. Notable for its numerous fortified sites atop the peaks of a spectacular volcanic landscape, Rapa has remained nonetheless an enigma in Polynesian prehistory. It has been linked, on the one hand, with its more famous and nearnamesake Rapa Nui (Easter Island), in hypotheses of Amerindian migration and the dire impacts of deforestation and societal isolation, and, on the other hand, with settlement and fort construction in the similarly cool and remote nearest neighbour to the southwest, New Zealand. Our project set out to construct a cultural sequence and palaeoenvironmental context so that consideration of such issues might profit from the existence of a more diverse and comprehensive database.

Rapa Island is located in a remote position at $27^{0} 35 \mathrm{~S}, 144^{\circ} 20 \mathrm{~W}$, in the subtropical South Pacific Ocean (Figure 1.1). In the form of a horseshoe, which reflects its origin as a breached caldera, Rapa has $38 \mathrm{~km}^{2}$ of land area and, lacking any barrier or fringing reef, its outer coast rises abruptly out of the sea towards jagged peaks, products of erosion around the caldera rim (Figure 1.2), the highest of which is Mont Perau, at $650 \mathrm{~m}$;

Where the steep sides of the jagged peaks reach the coast they form great cliffs falling vertically to the sea. The coast is bold with deep caves worn in it by the sea. Except around the bays in the coast, which have sandy beaches at their heads, the island is inaccessible. (Haslam 1982:83) 

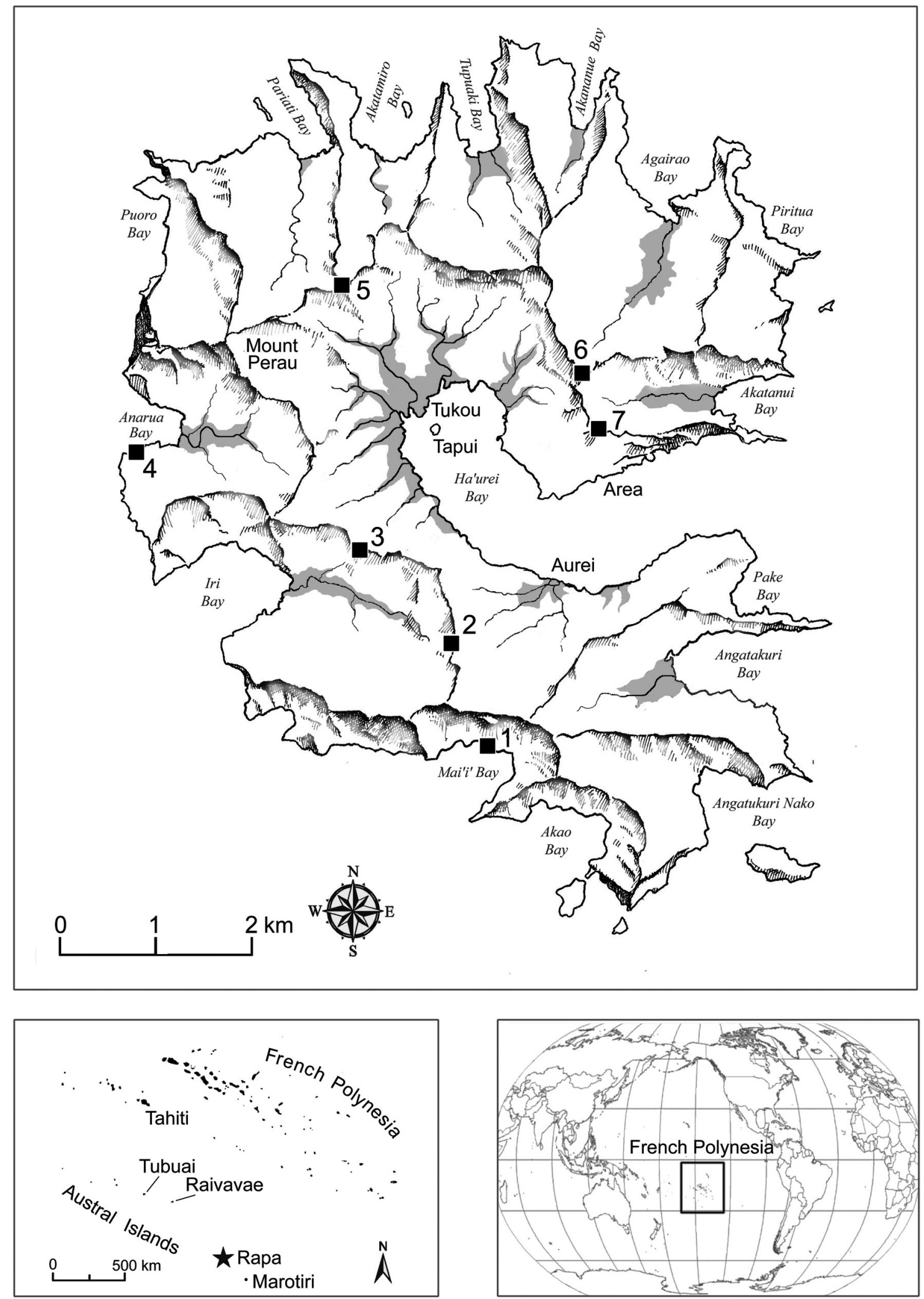

Figure 1.1. Rapa Island, showing the main topographical features and modern settlements.

Numbered squares indicate locations of previous research mentioned in this chapter: $1=$ Anapoiri Cave, $2=$ Tevaitau, $3=$ Moronga Uta, 4=Tangarutu Cave, 5=Kapitanga, $6=$ Potaketake, $7=$ Tapitanga. See Figures 3.1, 10.1 and 12.1 for the sites examined during the 2002 field season. Inset, the location of Rapa in the South Pacific Ocean and Austral Island group. Drafted by R. Van Rossman. 

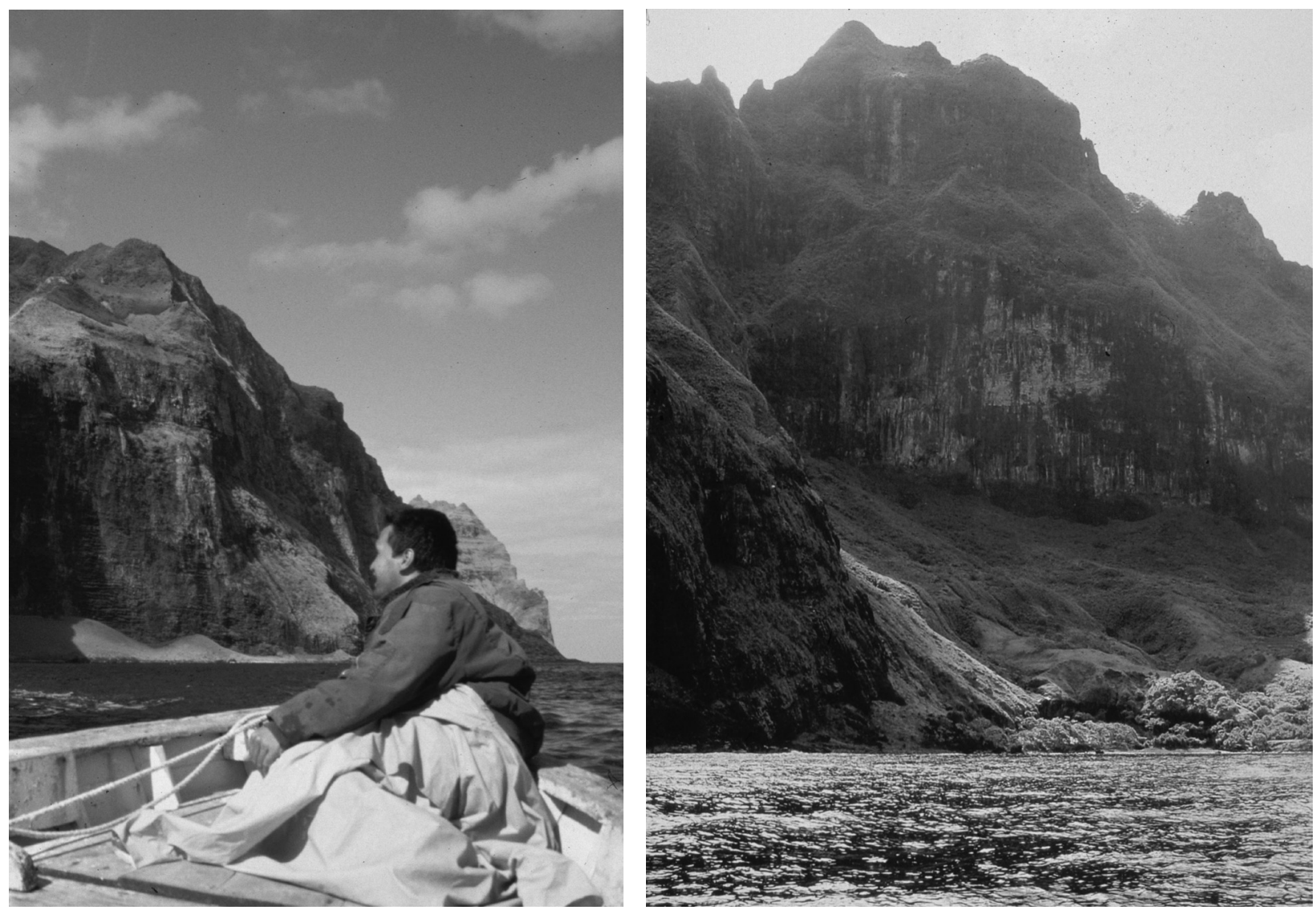

Figure 1.2. (a) The steep outer coast of Rapa near Akananue Bay. (b) Rapan cliffs on the northern coast. Photographs A. Anderson.

Topographically, the redeeming feature of Rapa for human habitation is its large, protected harbour with relatively extensive low and fertile ground at its head (Figure 1.3). The harbour was called Aurai in the 1820s (Chapter 2) and it has been called Ha' urei or Ahurei since the 1940s at least (Naval Intelligence Division 1943:253). However, Stokes (n.d.) called it 'Tairirau' and on an early map published by Hall (1868) it is labelled 'Boukakika' (Figure 1.4). The two main settlements of historical times, and today, are located opposite each other on Ha'urei Harbour. They were written as Harea and Aruhei by Hall (Figure 1.5), and today are Area and Ha'urei or Aurei respectively. We use Area for the smaller community on the north side of Ha' urei Bay and Aurei for the larger community, located to the southwest, to distinguish it from the bay name itself. It is worth noting here, as well, that the spelling of Rapan names is quite varied because of the historical influence of Tahitian on the Rapan dialect. Thus we get Taga and Tanga, Angairao and Agairao, Iri and Hiri and so on. Neither we, nor other writers, have standardised the spelling.

About $83 \mathrm{~km}$ to the east-southeast of Rapa lie the bare, uninhabited Marotiri (Bass) Islets. They have about $2 \mathrm{~km}^{2}$ of surface area, and bear some remains of stone-built structures (Ferdon 1965b:71). Rapa and Marotiri are part of the Austral archipelago, named by the French geographer Malte Brun (Ellis 1838:363), but they are sometimes separated out, and once were known as the Bass group, in recognition of their relative remoteness from the other Austral Islands (e.g. Naval Intelligence Division 1943; Kooijman 1972; Haslam 1982:82). The nearest inhabitable island to Rapa is Raivavae, $537 \mathrm{~km}$ to the northwest, but the administrative centre of the Australs is on Tubuai Island, $730 \mathrm{~km}$ from Rapa. 


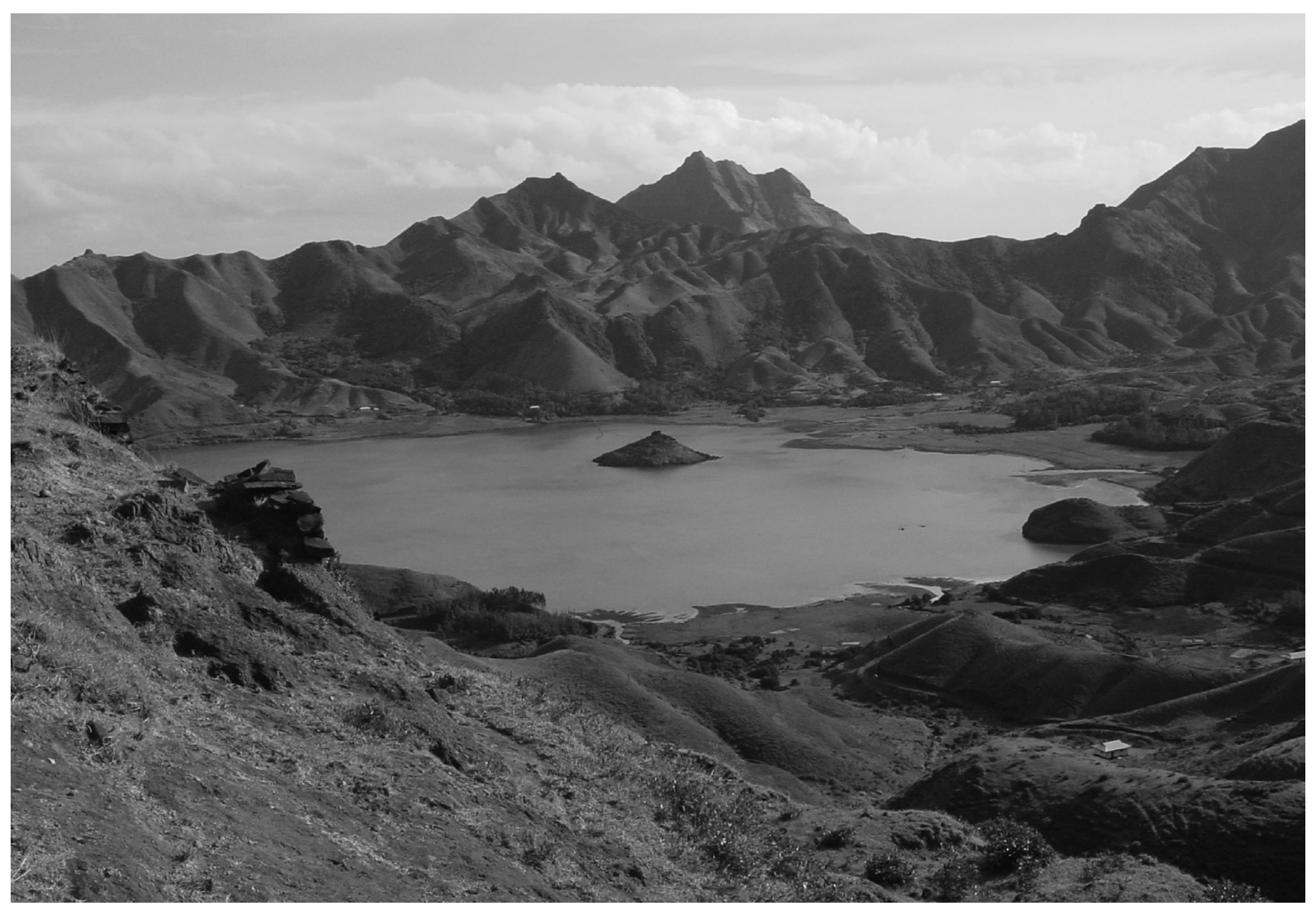

Figure 1.3. Ha'urei Bay, showing lowlands, taro plantations in the Tukou region and Tapui Island. Hilltop fortifications are visible on several of the highest peaks. Photograph D.J. Kennett.

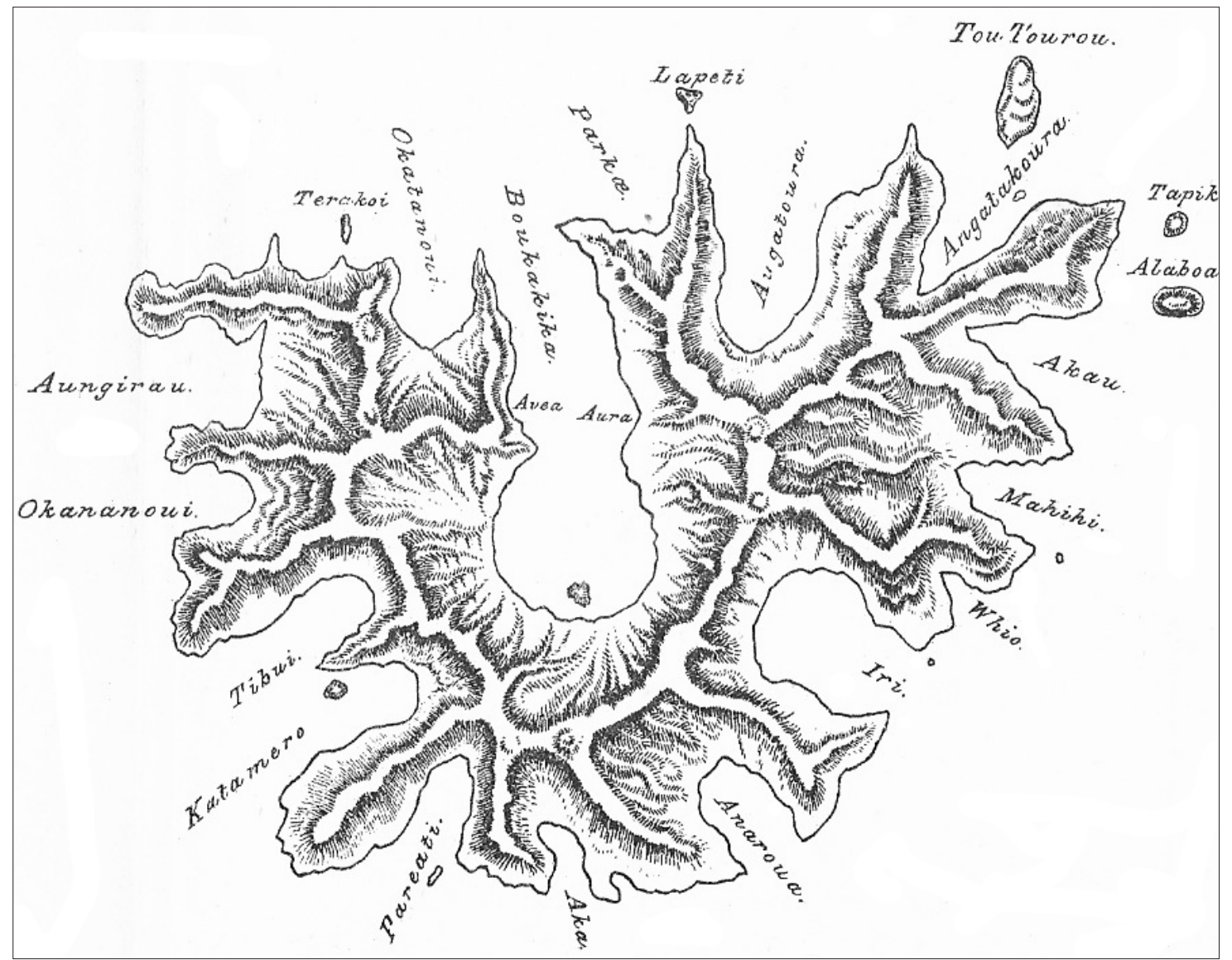

Figure 1.4. Map of Rapa published by Hall (1868:facing p. 80). 


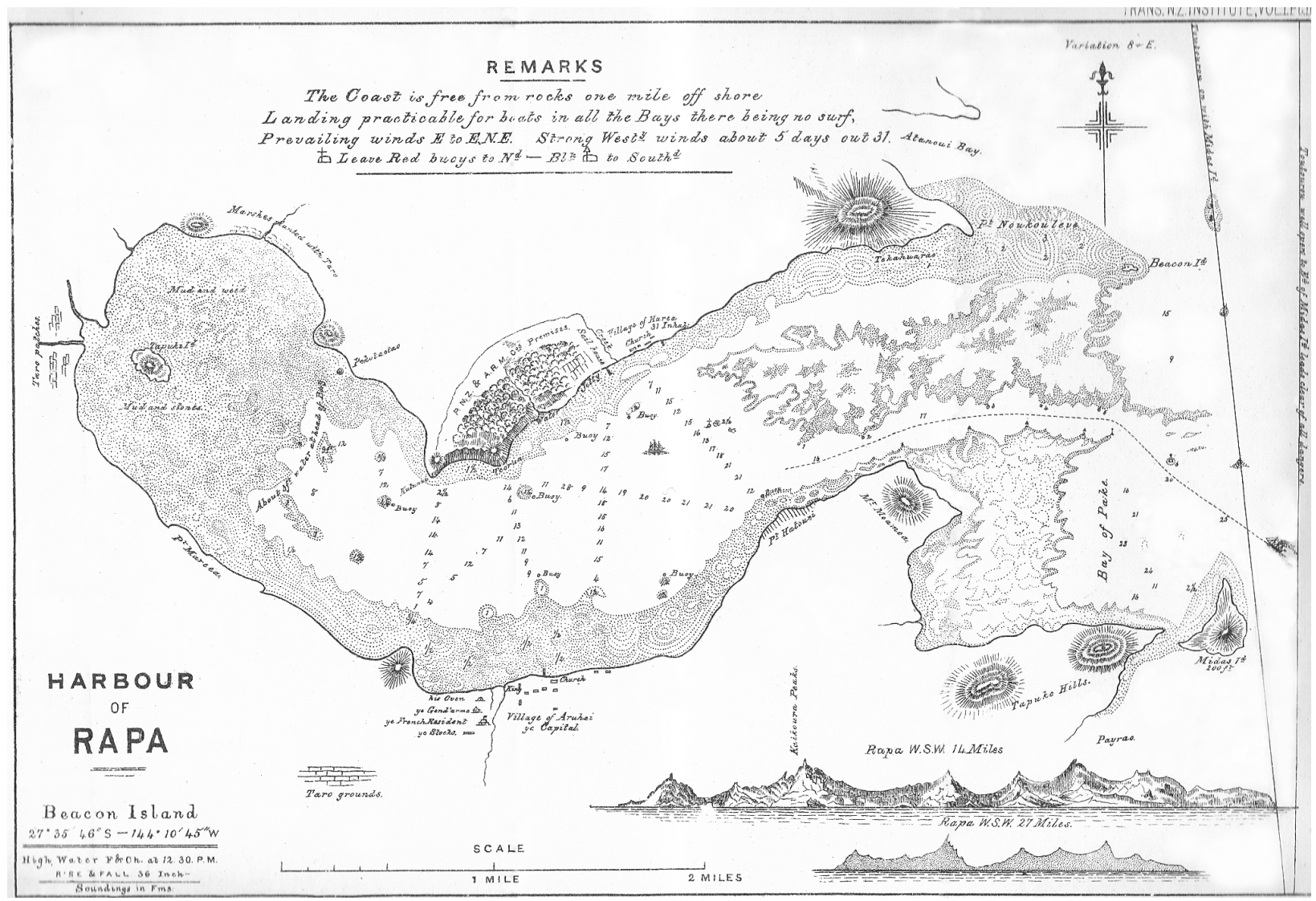

Figure 1.5. Plan of the harbour at Rapa, showing the main settlements (Hall 1868:facing p. 76).

The Rapan climate is relatively cool, cloudy and windy. Mean daily maximum temperatures at the coast vary from $26^{\circ} \mathrm{C}$ in February to $20^{\circ} \mathrm{C}$ in July, about $3^{\circ} \mathrm{C}$ below those elsewhere in the Australs. Rainfall is high, at $2840 \mathrm{~mm}$ per annum, and 156 days a year have more than $70 \%$ cloud cover. Rapa has mainly easterly conditions in the summer (60\% of winds from an easterly quarter in February), but in the winter there are numerous westerlies (32\% in July) that create cool, squally conditions (Haslam 1982:56). Wind directions change every few days and all winds from the east-northeast through south to the north-northwest are described by Rapans as 'cold and strong'; the only warm winds are from the north (Stokes n.d.:4).

Taken under French protection in 1867 and annexed in 1881, Rapa was once on the main shipping route across the Pacific between New Zealand and the Panama Canal. A coaling station was established in Ha'urei Harbour by the Panama-New Zealand \& Australia Royal Mail Company (PNZARMC) in 1867, but as steamers were replaced by motor vessels, Rapa became more isolated again. It lacks suitable ground for an airfield, and is thus accessible only by sea. In recent times, the population has varied around a total of 400, most of it in Aurei village on the south side of Ha'urei Harbour (Figure 1.6). Cultivation of taro and fishing are the main subsistence pursuits, and there is also hunting of feral goats and cattle, along with some fowling along the cliffs, but the economy is subsidised heavily by the French Polynesian exchequer.

\section{Discovering Rapan archaeology}

The archaeological significance of Rapa has rested almost entirely upon its dramatic landscape of sculpted peaks along the mountain rim that almost encircles Ha'urei Harbour. These were observed as inhabited places during the first European visit in 1791, when they were described 


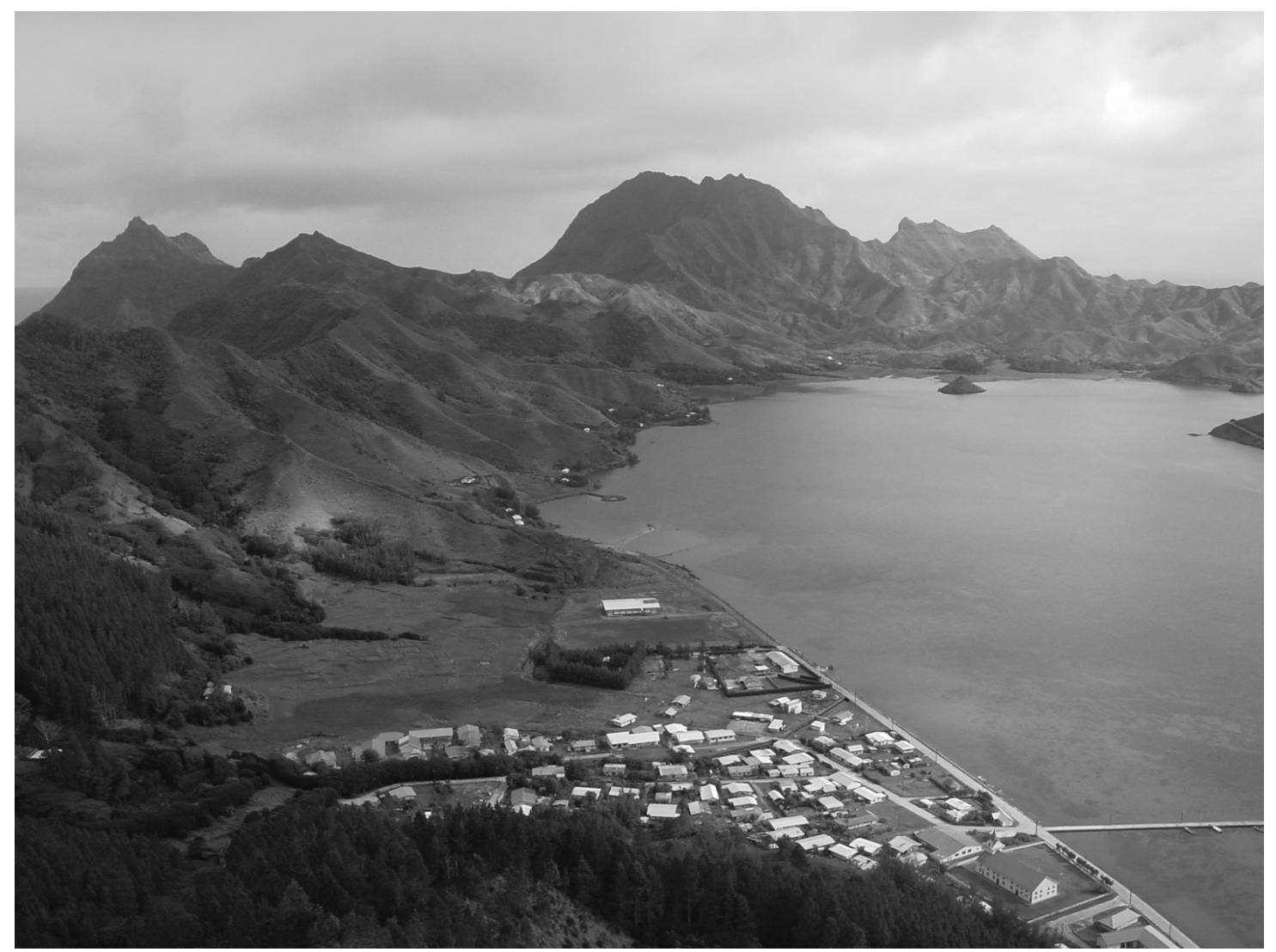

Figure 1.6. Aurei village taken from the site of Ororangi just to the southeast and looking northwest up Ha'urei Bay. Photograph D.J. Kennett.

as 'fortified places resembling redoubts' and likened to New Zealand Maori pa (Vancouver 1791 in Lamb 1984:374). Ellis (1838:364) noted that the fortifications:

are so constructed as to render them impregnable by any means which the assailants could bring against the besieged. Wars have not been frequent among them, and, when they have existed, have been less sanguinary than those among the islands to the northward.

By the late 19th century, the Rapan forts were being drawn into a popular discourse about ancient Polynesian history and ethnology that sought to link the remote islands of Polynesia to continental origins, either in Asia or South America, notably by reference to megalithic remains. This focused, of course, on Easter Island, but the apparent linguistic, and implicitly ancestral, connection of Rapa-nui (Big Rapa), as Easter Island was also known, to Rapa-iti (Little Rapa), as Rapa was then commonly called, coupled with massive structural remains in both places, encouraged speculation about ancient cultural connections between the two (see Smith 1910).

Captain John Vine Hall (1868:133) published a plan and drawings of two Rapan forts (Figures 1.7 and 1.8). The source of this material is unclear. He was on Rapa for only two days and did not visit any of the forts (Hall 1868:134). His information about them, and indeed most of his information about Rapa generally, seems to have come from his colleague in the PNZARMC, Captain McKellar, superintendent of the coaling station. Hall reported, nevertheless, that:

On the summits of many of the steep hills are to be seen these square fortresses, some of very elaborate construction. But what is very singular, they are mostly solid within. The stones are well squared, of very large size, and well cemented. (Hall 1968:133) 
Professor MacMillan Brown visited Rapa in 1917 (Best 1975:415), climbed up to the highest fort and found it a disappointingly rudimentary structure of small lava slabs, 'which had by long infiltration of some adhesive element almost solidified into the appearance of a natural rock'. Yet, distance lent enchantment to his view of others, for, like Captain Hall, he saw:

... away in the distance and across the harbour ... the outlines of much more elaborate forts, with terrace upon terrace, parapets and moats, and in almost every case there rose above all a similar solid tower which was evidently meant as an outlook into the valleys beyond. These forts were, in short, specimens of the rude megalithic masonry that I afterwards saw in the Society islands, and still more in the Marquesas, consisting of great stones roughly squared to fit their place without cement. (MacMillan Brown in Best 1975:415)

In 1921, the Routledges visited Rapa for 10 days while on a cruise of French Polynesia, with the object of finding traces of culture analogous to that of Easter Island (Routledge and Routledge 1921:438). They visited eight of the forts (known as pare, and recorded by them as palé) and described their general construction, noting that, far from being structures of stone blocks and cement, they were:

... in some cases little more than excavated terraces, of the nature of pure earthworks, but usually the summit of the hill has been turned into a round tower or keep. In such cases, the rock is sometimes utilized with no addition, or only a small amount of walling, but where this is not adequate the core has been faced ... with a dry masonry of basaltic fragments ... in all cases [the towers] are solid, and never contain apartments. (Routledge and Routledge 1921:454-455)

The pare each occupied one to three acres (0.4-1.2 ha) in extent and consisted of flights of terraces, up to six in a series, formed by simple cutting or by cut and fill with stone facings. Ditches restricted access into the fort. It was not clear to what extent the pare had been permanent villages, for:

On the terraces of the forts there were never found buildings, nor foundations of buildings, nor even subterranean shelters worthy of the name; the only depression in the ground had evidently been excavated for purposes of cooking. Huts made of grass only would, no doubt, have disappeared, but would be peculiarly unsuitable for so exposed a position. It seems most probable that the forts were designed only to serve as a refuge for the inhabitants of the valley below in case of sudden raid or emergency. (Routledge and Routledge 1921:455)

As John Stokes (Chapter 2) was already at work on Rapa, the Routledges abandoned their plan to work there and moved to Mangareva. Stokes' (n.d.) notes and drafts for his proposed Bishop Museum monograph on Rapa show that he spent considerable time visiting the pare and locating other archaeological sites. The salient details of his work are noted in Chapters 2, 3 and 12.

Using Stokes' notes, Buck summarised the construction of pare thus:

A ridge with a peak was selected and the summit levelled off to form the topmost terrace. The sides were cut down with digging implements of pointed wood and rude adzes of dyke basalt, until a second terrace could be formed of sufficient width to accommodate houses. The military architects of the day continued the plan of successive terraces, which necessitated high walls at the back. The razorback on the ridge leading to the peak was levelled off and the sides were cut to increase the steepness against assault. Deep ditches were cut across the main ridge on either side of the citadel to improve the defences. On the secondary ridges leading up to the main fort, further terraces were dug to provide house accommodation and outposts for defence. The back walls of the terraces, particularly near the citadel, were further 

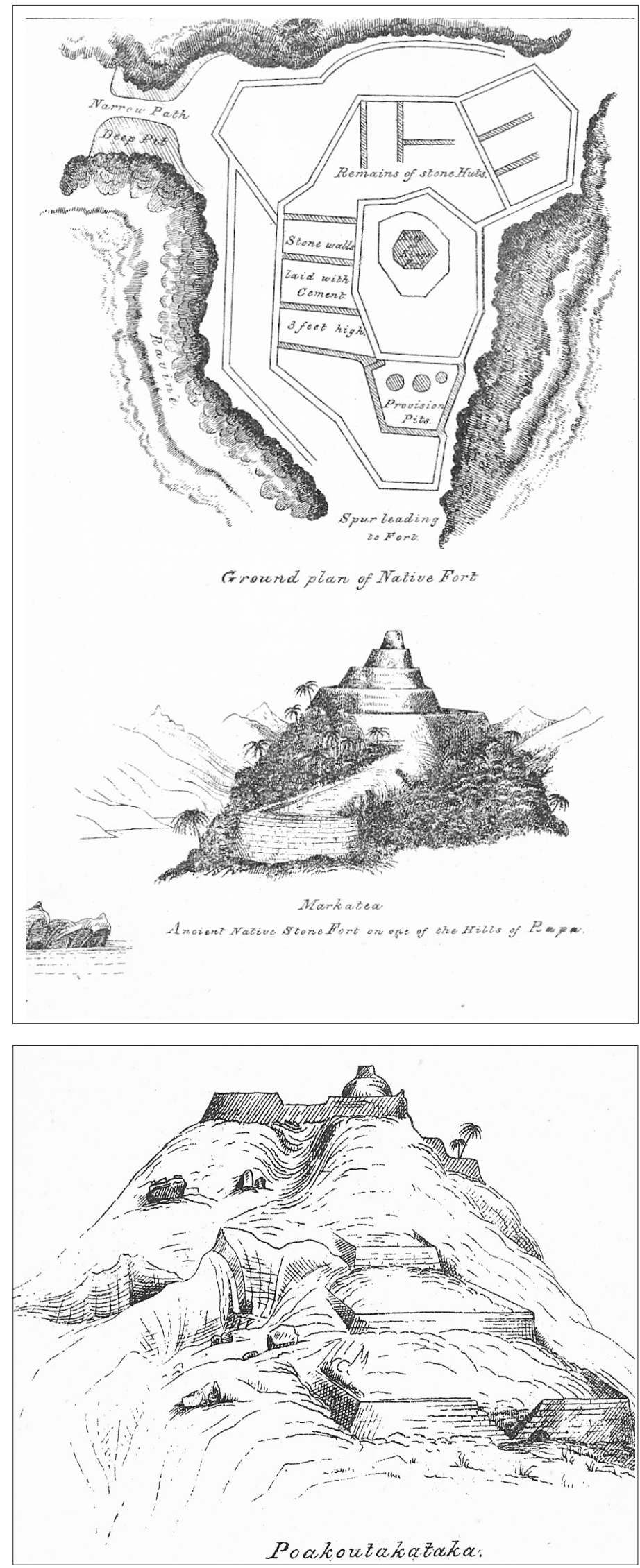

Figure 1.7. Drawing and plan of Markatea pare (Hall 1868:facing p. 80).

Figure 1.8. Sketch of Poakoutakataka fort (Hall 1868:facing p. 80). 
reinforced with stone slabs carefully built in to protect the earth face against the detrition of wind and rain. Projecting stones formed footholds by which the defenders could retreat from terrace to terrace ... On the topmost terrace of the citadel peak the high chief resided. (Buck 1954:183)

He went on to propose that, 'the peculiar geographical formation' of Rapa had induced the development of fortifications and, alluding to the similar pa of New Zealand, which he knew well, suggested that if he had managed to visit Rapa he might, 'have sensed an affinity that personal contact may convey with more subtlety than the written words of others' (Buck 1954:184). In later discussion, Buck (1954:288) implies a developmental sequence of fortifications in which the Rapan structures occupy a middle ground between ditched enclosures, as in Tonga, and more complex and permanently occupied Maori pa that combined terrace and ditch with palisades.

\section{Earlier archaeological research}

Although Stokes had cleared part of the pare Morongo Uta and put spade pits into a number of sites, the first systematic archaeological research on Rapa was by the Norwegian Archaeological Expedition to Easter Island and the East Pacific (1955-1956) organised by Thor Heyerdahl (Heyerdahl and Ferdon 1961, 1965). Ferdon (1965:12-13) recorded stone structures above the shore in Ha'urei Bay and surveyed the pare at Potaketake, Tapitanga and Kapitanga. Smith (1965a) investigated stone-outlined features which he thought had been houses and, from an exposed oven in a small terrace (R-16) at the head of Ha'urei Harbour, he took a charcoal sample that was radiocarbon dated to ca. AD 1337 (M-707), the earliest date obtained on Rapa at that time (Smith 1965a:83). Anapoiri, a burial cave, and an oven site were recorded in Mai' i' Bay. Historical and modern burials were also investigated by Smith (1965b), with scant regard to propriety or cultural sensitivity.

The main research was on the large pare, Morongo Uta (Mulloy 1965). This is a complex structure occupying several ridges and their junction. It consists mainly of terraces covering an area of about $5400 \mathrm{~m}^{2}$ :

For the most part they were constructed by excavating horizontal floors into the steep slopes and shoring up the front sides of these with dry masonry walls, or planing the ridge-tops and surrounding rectangular areas with masonry. On most of these terraces presumably stood houses of perishable materials. (Mulloy 1965:23)

The entire site was cleared, overburden - generally from terraces higher up - was removed and many of the displaced stones were used to repair damaged terraces. Mulloy (1965:25) determined that the site had been built from its core outward, beginning with the tower, and suggested that it was first constructed as a fort and then developed later into a fortified village. Basalt prisms were used preferentially in walls and facings, but as these became locally scarce, other stones were used as well. Low walls or parapets lined the outer edges of some terraces and other low walls acted as terrace partitions. The terraces or enclosures, approximately 85 in all (Mulloy 1965:53, cf. Stokes n.d., Chapter 2), are assumed to have been platforms for perishable houses. Fourteen stone-kerbed fireplaces, complete with ash and charcoal, were found, but the very wet weather that prevailed for much of the short field season precluded a systematic search for post holes.

Recovered on the terraces were 60 each of adzes (whole and fragmentary) and pounders. There were also some anvils and polishing stones, several probable sling stones and the charred remains of a net or netting bag. Mulloy (1965:57) commented on the scarcity of evidence for storage of food or water, and of deep midden deposits, suggesting that occupancy might have 
been temporary. Two samples produced radiocarbon dates of $310 \pm 300 \mathrm{bp}$ and $210 \pm 200 \mathrm{bp}$ (Mulloy 1965:59), which are essentially modern. They lend support to the Rapan belief that the site was occupied until the European era.

In summary, Ferdon (1965) proposed that the pare, as all the fortified peaks can be called (Ferdon (165:69) saw little in the distinction made by Stokes (n.d.) between fortified villages and refuge villages), were all built quite rapidly by large groups of organised labour and according to fairly simple architectural principles founded on the idea of a central fort surrounded by defended house terraces with defensive ditches externally and internally, and outlying clusters of undefended or lightly defended settlement (auga). Within the pare, small niches in the back walls of terraces held two lines each of four to seven small vertical stones, and a few similar features were recorded out on the open house terraces. These are almost certainly remains of shrines (Ferdon 1965:74-75).

The Rapan results of the Norwegian expeditionary research were soon brought into Heyerdahl's more general thesis of Polynesian origins. The pare were seen initially as 'mysterious pyramids' (Heyerdahl 1958:288) and, on excavation of Morongo Uta, as fortified villages, once occupied by oval huts, 'suspiciously reminiscent of Easter Island' (Heyerdahl 1958:341). Heyerdahl thought that the pare and other signs of habitation on the ridge-tops were evidence that the Rapan population feared an external enemy, perhaps from Easter Island, and that having 'built themselves curved reed houses and rectilinear stone ovens ... instead of rectilinear houses and round earth ovens as on all the islands in the neighbourhood' (Heyerdahl 1958:343), they had come from Easter Island as refugees at the time of the traditional wars. It was implicit in this view that pare were built more or less at once by the colonising population, rather than later in the settlement sequence.

In 1984, in the course of a French survey of the Rapan environment, a radiocarbon date of $370 \pm 60$ bp was obtained from Tangarutu Cave, in Anarua Bay (Walczak 2001:250). In 1997, a French doctoral student, Jérôme Walczak (2001:297-303, 2003) undertook some small excavations at the site (Chapter 3). He also surveyed the remains of a number of the abandoned village sites and other structures on the low ground around Ha'urei Bay, in particular, which, added to some similar work by the Norwegian expedition, has helped to balance the early emphasis on forts.

However, the focus of Walczak's $(2001,2003)$ research in Rapa remained the nature of the pare: whether they were simply refuge forts necessitated by chiefly competition driven by population growth, which was the prevailing model, as articulated by Hanson (1974), or whether they had more complex functions, including ritual significance. Walczak discusses the latter proposition:

Ces pare peuvent selon nous être assimilés à des villages d'altitude. Cet terrasses sont dominées par un promontoire central, qui pourrait être un centre religieux comparable à ce quétaient les marae dan d'autres îles de la Polynésie orientale. (Walczak 2003:30)

Assuming that the relatively young age of occupation at Tangarutu represents the era of early settlement, then the age of pare construction cannot have been much later, in which case, he concludes, it is unlikely to have been compelled by population pressure, and more probably reflects the needs of ritual use.

Enlarging on this theme, Walczak emphasises the difference between public religious cults, sustained largely by chiefs, and domestic religious observances, and proposes that it was not so much depopulation per se, but chiefly rejection of the public cults that led to post-European abandonment of those pare, or the higher levels of pare, that were associated with public ritual 
functions, while some pare or parts of them, remained in use until the later 19th century by the common people; Tevaitau being one (Walczak 2001:276). He concludes that pare were essentially symbolic in function, perhaps modelled on the form of the burial island of Tapui in Ha'urei Harbour. Consequently:

Grâce à cette hypothèse, nous pouvons expliquer leur unité de style architectural, leur situation surélevée, leur configuration en réseau - voire en complexes - et l'absence de murallie ou de fossé protecteur. (Walczak 2001:277)

There are, therefore, several competing hypotheses concerning the origins and functions of fortified settlements in Rapa, as there are elsewhere, and an implication that they may have occupied more complex roles in Rapan society than purely defence.

\section{The 2002 expedition}

Although previous research had produced substantial information about Rapan archaeology, notably about the hill forts and associated material culture, there was little context in 2002 to interpret these impressive sites. Indeed, the archaeology of Rapa was essentially a story about castles in the air; coastal occupation and the concerns of life in the valleys had been barely noticed, much less investigated. The age of Rapan colonisation was unknown, the age of fort construction was largely unknown, the sequence of settlement pattern was based on a plausible proposition, but one that remained untested, and the human impact on the island environment and its possible consequences for settlement pattern and social development remained unexplored. Each of these issues is important, not only to understanding the prehistory of Rapa, but also in the wider contexts of East and South Polynesian prehistory. The project was organised, consequently, into three research areas: island colonisation, the origins of fortification, and trends in environmental change. This had the coincidental advantage of dividing fieldwork into the three main zones, respectively, of the Rapan landscape: the bays and harbour, the high ground, and the valleys and swamps.

\section{Island colonisation}

The key issue of East and South Polynesian colonisation, though far from the only one, was the chronology. Earlier research (see summary by Kirch 1986; Kirch and Kahn 2007) had reached a consensus that colonisation began in the early first millennium $\mathrm{AD}$, if not earlier, in tropical East Polynesia and there were arguments for exploration of New Zealand about the same time (Sutton 1987; Holdaway 1999). Yet, renewed chronological research on samples from the same provenances of key sites regarded as early, such as Haatuatua and Hane in the Marquesas (Rolett and Conte 1995; Anderson and Sinoto 2002), Vaitootia-Faahia and Maupiti in the Societies (Anderson et al. 1999; Anderson and Sinoto 2002), South Point in Hawaii (Dye 1992), Anakena on Easter Island (Steadman et al. 1994) and Papatowai and Wairau Bar in New Zealand (Anderson and Smith 1992; Higham et al. 1999), produced manifestly later dates, suggesting no colonisation of East Polynesia before about AD 900-1000 (Anderson and Sinoto 2002), nor of South Polynesia before AD 1200 (Anderson 2000, 2006), or possibly later (Wilmshurst et al. 2011). As Rapa is both unusually remote and well south of central East Polynesia, it was a moot point whether its colonisation chronology was closer to that of South or that of East Polynesia, an issue that has interesting implications for early migration pace and patterning.

In addition to chronology, we wanted to know about the behaviour of the early settlers. Where did they live on Rapa and was there evidence of houses and other structures? Did 
agriculture begin with colonisation or somewhat later? Was there evidence of faunal depletion or extinction, of land birds especially? Were turtles, marine mammals, and large fish and shellfish proportionately more common in early habitation levels? Were the rather distinctive Rapan adzes an early development? Was there any evidence of distant contacts, in the form of obsidian or other exotic materials or artefacts?

Based on research in other Pacific Island groups, we predicted that early colonists would have preferred settling on the coast in relatively sheltered bays with easily accessible fishing, reliable freshwater sources and near prime agricultural lands. We focused first on Ha'urei Bay, which stands out as meeting those criteria and which is, of course, the preferred locus of modern habitation and gardening. We travelled around the outside coast of Rapa in several expeditions by open boat, and also by walking over the ridges from the harbour, in order to investigate each bay for potential evidence of early settlement (Chapter 3). The results of this research, almost entirely around the coast, are described in Chapters 3-9.

\section{Origins of fortification}

Competition for resources is an important driving force in the development of social and political complexity (Kennett and Kennett 2000) and it has been argued repeatedly that it played a crucial role in the development of Pacific Island chiefdoms (Kirch 1984; Rechtman 1992; Ladefoged 1993; Field 1998, 2004; Kuhlken 1999). Fortified hilltop villages in remote Oceania provide the most obvious archaeological evidence for warfare prior to European contact and indicate that inter-village conflict was an important component of social and political life (Green 1967; Best 1993; Kirch 1994; Burley 1998), although recently a more nuanced understanding of the complex roles of fortified sites has begun to emerge (Walczak 2001; Sutton et al. 2003).

The hyper-fortified nature of Rapa has often been used as an example of Polynesian inter-village hostilities (Kirch 1984:212). But these fortifications had not been investigated in sufficient depth to understand their age, origins or development. The archaeological studies by the Norwegian expedition (Heyerdahl and Ferdon 1965) revealed the remains of house platforms, hearths and habitation debris at the pare, but a basic chronological framework, necessary to understand the development of these villages, was lacking. In addition, artefact analysis was confined to large objects and no detailed midden constituent work was conducted.

The primary objective of our fieldwork was to recover organic material suitable for constructing a radiocarbon chronology of fortification on Rapa. We mapped and tested (auger probes and small sample test units) 14 hilltop fortifications to recover organic material for AMS radiocarbon dating (see Chapters 11 and 12). We also excavated larger test units at four hilltop village sites (Tevaitau, Ororangi, Potaketake and Tapitanga) to obtain additional information about the distribution of artefacts and ecofacts (Chapter 12). IKONOS and Quickbird satellite imagery and a laser transit were used to map the domestic and defensive features at these locations. Based on previous excavations at Morongo Uta, it appeared that the deposits were relatively shallow (ca. $1 \mathrm{~m}$, Mulloy 1965). A standard bucket auger was used to probe subsurface deposits for concentrations of organic material (shell or charcoal) necessary for AMS radiocarbon dating. When concentrations of material were encountered, small test units $(50 \times 50 \mathrm{~cm}$, larger if necessary) were excavated to obtain samples from stratigraphically intact deposits.

\section{Palaeoenvironmental change}

Recovery and analysis of sedimentary cores for inorganic and organic materials indicative of former environments is a long-established and well-proven technique in palaeoenvironmental research. Debate about its application to Polynesian issues (e.g. Kirch and Ellison 1993; Parkes 
1998; McGlone and Wilmshurst 1999; Kirch 2007 contra Anderson 1994, 1995; Prebble 2007) highlighted some problems in interpretation and dating which have been addressed in more recent research. As Rapa was once covered by temperate rainforest but at some point in the prehistoric past became almost completely denuded of forest, pollen analysis was the most suitable approach to that sequence. Pollen analysis of shifts in plant communities provides a basis for the detection of anthropogenic influence in deforestation and provides a proxy for the history of agricultural expansion (Hope 1996; Hope and Pask 1998).

The general strategy of the Rapan project in this matter was to focus on the wetlands around the head of Ha'urei Harbour, on the assumption that they, as the largest and most readily accessible area of coastal flats, would have been the first choice for introduction of agriculture and then for later development of intensive taro cultivation. Other bays where wetlands were cored included Angatakuri, Iri, Anarua, Pariati, Agairao and Akatanui. The methods and results of our field and analytical research are described in Chapter 10.

\section{Limitations}

The data reported here come from small samples, particularly the archaeological data that arose from excavations, which, in other circumstances, might be regarded as hardly more than test pits. Another field season, at least, would have been desirable in several respects: to extend excavations in the main coastal site at Tangarutu, to investigate terraces and other features, especially around the harbour, which appear to represent former villages and isolated houses, to extend excavations on the extensive pare sites, and to undertake systematic research on the agricultural systems. However, as the project occurred at a time when archaeological funding for Polynesian projects was especially scarce and the attention of the principal investigators was being drawn elsewhere, this was just not possible. This monograph, then, should be regarded as an interim description of the prehistory of Rapa.

\section{Acknowledgements}

The field team (Figure 1.9), consisted of Atholl Anderson and Matiu Prebble (The Australian National University), Douglas Kennett, Yann Doignan, Sarah McClure and Nathan Wilson (University of Oregon), and Roti (Rosine) Oitokaia (Université de Polynésie Française). Eric Conte (Université de Polynésie Française) was involved in the development of the project and organised the expedition travel from and to Tahiti, but he was unable to participate in the fieldwork. Including several days in Papeete, and also in Tubuai, the expedition was from July 1 to August 25, 2002, of which 43 days were spent on Rapa.

The expedition was funded primarily by the National Geographic Society (Grant 7059-01), to which our gratitude is due, and we also thank the universities represented for their supporting subventions. For a research permit, and permission to remove material temporarily from French Polynesia, we thank the Mission d'Aide Financière et de Coopération Régionale of the HautCommissariat de la République en Polynésie Française, and also Martine Rattinassamy (Le Chef de Service) and Tamara Maric of the Service de la Culture et du Patrimoine in Tahiti.

On Rapa, we received permission to undertake our research from the Mayor and Council. Our stay was made both profitable and pleasurable by our generous hosts, Annette and Freddy Riaria and Faraire Cerdan. For assistance in particular matters, we thank Freddy Riaria for arranging travel by boat around the island, and Teraura Oitokaia for information on traditional fishing, fowling and shellfishing. 
For collaboration in post-fieldwork research we thank: Alan Tennyson (Te Papa, National Museum of New Zealand), Yolanda Vogel (New Zealand Historic Places Trust and University of Otago), Katherine Szabó (ANU and University of Wollongong), Judith Cameron (ANU), Jacob Bartruff (University of Oregon), Virginia Butler (Portland State University), Bruce Winterhalder (University of California, Davis) and John Southon (University of California, Irvine). We are also grateful for Rusty Van Rossman's assistance with drawings, graphics and maps, and for comment on the manuscript by Terry Hunt (University of Hawaii at Manoa), and Richard Walter (University of Otago).

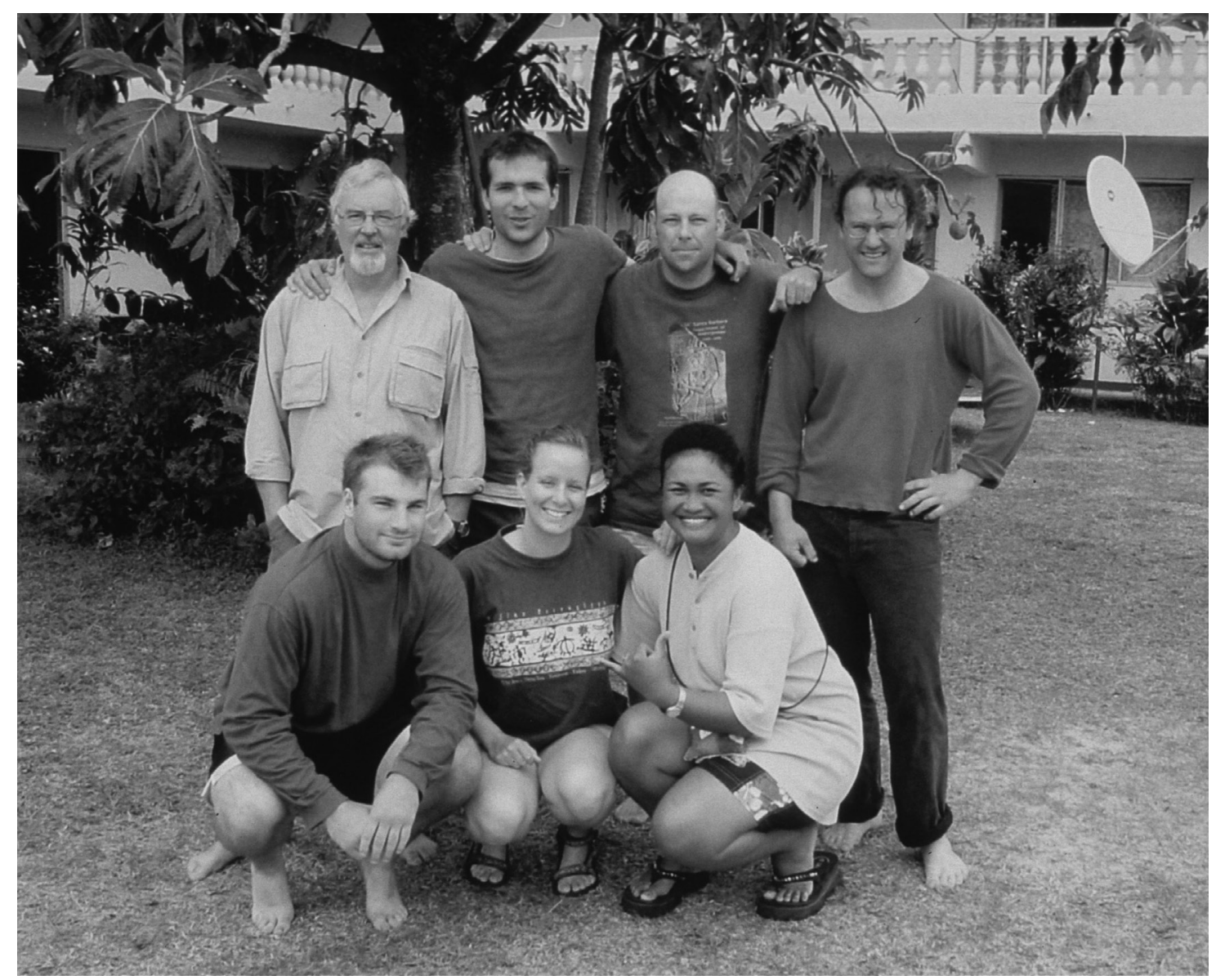

Figure 1.9. The 2002 Rapan field team on Tubuai Island before embarking for Rapa. Left to right, back row Atholl Anderson, Yann Doignan, Douglas J. Kennett, Matiu Prebble; front row Nathan Wilson, Sarah B. McClure, Rosine Oitokaia. 


\section{References}

Anderson, A.J. 1994. Palaeoenvironmental evidence of island colonization: a response. Antiquity 68:845-847.

Anderson, A.J. 1995. Current approaches in East Polynesian colonization research. Journal of the Polynesian Society 104:110-132.

Anderson, A.J. 2000. The advent chronology of south Polynesia. In: Wallin, P. and Martinsson-Wallin, H. (eds), Essays in honour of Arne Skjolsvold 75 years. Occasional Papers of the Kon-Tiki Museum 5:73-82.

Anderson, A.J. 2002. Faunal collapse, landscape change and settlement history in Remote Oceania World Archaeology 33:375-390.

Anderson, A.J. 2006. Retrievable time: prehistoric colonization of South Polynesia from the outside in and the inside out. In: Ballantyne, T. and Moloughney, B. (eds), Disputed Histories: imagining New Zealand's pasts, pp. 25-41. University of Otago Press, Dunedin.

Anderson, A.J. and Smith, I.W.G. 1992. The Papatowai site: new evidence and interpretations. Journal of the Polynesian Society 101:129-158.

Anderson, A.J., Conte, E., Clark, G.R., Sinoto, Y. and Petchey, F.J. 1999. Renewed excavations at Motu Paeao, Maupiti Island, French Polynesia: preliminary results. New Zealand Journal of Archaeology 21:47-66.

Anderson, A.J. and Sinoto, Y.H. 2002. New radiocarbon ages of colonization sites in East Polynesia. Asian Perspectives 41:242-257.

Best, E. 1975. The Pa Maori. Government Printer, Wellington.

Best, S. 1993. At the Halls of the Mountain Kings. Fijian and Samoan Fortifications: Comparison and Analysis. The Journal of the Polynesian Society 102(4):385-447.

Buck, Sir P.H. 1954. Vikings of the Sunrise. Whitcombe and Tombs, Christchurch.

Burley, D.V. 1998. Tongan Archaeology and the Tongan Past, 2850-150 B.P. Journal of World Prehistory 12(3):337-392.

Dye, T. 1992. The South Point radiocarbon dates thirty years later. New Zealand Journal of Archaeology 14:89-97.

Ellis, W. 1838. Polynesian Researches, during a residence of nearly eight years in the Society and Sandwich Islands. Volume III, Fisher, Son and Jackson, London.

Ferdon, E.N. 1965a. Report 2: A reconnaissance survey of three fortified hilltop villages. In: Heyerdahl, T. and Ferdon, E.W. (eds), Reports of the Norwegian Archaeological Expedition to Easter Island and the East Pacific, Volume 2 Miscellaneous Papers, pp. 9-21. Monographs of the School of American Research and the Kon-Tiki Museum, 24 Pt. 2, Esselte AB, Stockholm.

Ferdon, E.N. 1965b. Report 4: A summary of Rapa Iti fortified villages. In: Heyerdahl, T. and Ferdon, E.W. (eds), Reports of the Norwegian Archaeological Expedition to Easter Island and the East Pacific, Volume 2 Miscellaneous Papers, pp. 69-87. Monographs of the School of American Research and the Kon-Tiki Museum, 24 Pt. 2, Esselte AB, Stockholm.

Field, J.S. 1998. Natural and Constructed Defenses in Fijian Fortifications. Asian Perspectives 37:32-58.

Field, J.S. 2004. Environmental and climatic considerations: a hypothesis for conflict and the emergence of social complexity in Fijian prehistory. Journal of Anthropological Archaeology 23:79-99.

Green, R.C. 1967. Fortification in Other Parts of Tropical Polynesia. New Zealand Archaeological Association Newsletter 10:96-113.

Hall, J.V. 1868. On the island of Rapa. Transactions of the New Zealand Institute 1:128-134.

Hanson, F.A. 1970. Rapan Lifeways: society and history on a Polynesian island. Little and Brown, Boston. Haslam, D.W. 1982. Pacific Islands Pilot, Volume III. Hydrographer of the Navy, Taunton.

Heyerdahl, T. 1958. Aku-Aku: The Secret of Easter Island. Allen and Unwin, London.

Heyerdahl, T. and Ferdon, E.W. (eds), 1965. Reports of the Norwegian Archaeological Expedition to Easter Island and the East Pacific, Volume 2 Miscellaneous Papers. Monographs of the School of American Research and the Kon-Tiki Museum, 24 Pt. 2, Esselte AB, Stockholm. 
Higham, T.G.F., Anderson, A.J. and Jacomb, C. 1999. Dating the First New Zealanders: the chronology of Wairau Bar. Antiquity 73:420-427.

Holdaway, R.N. 1999. A spatio-temporal model for the invasion of the New Zealand archipelago by the Pacific rat Rattus exulans. Journal of the Royal Society of New Zealand 29:91-105.

Hope, G.S. 1996. Quaternary change and historical biogeography of Pacific Islands. In: Keast, A. and Miller, S.E. (eds), The Origin and Evolution of Pacific Island Biotas, New Guinea to Eastern Polynesia. SPB Publishing, Amsterdam.

Hope, G.S. and Pask, J. 1998. Tropical Vegetational Change in the late Pleistocene of New Caledonia. Palaeogeography, Palaeoclimatology, Palaeoecology 142:1-21.

Kennett, D.J., Anderson, A.J., Prebble, M. and Conte, E. 2003. La colonization et les fortifications de Rapa. In: Marchesi, H. (ed), Bilan de la recherché archeologique en Polynesie francaise, pp. 165-170. Dossier d'Archéologie Polynésienne 2. Service de la Culture et du Patrimoine, Punaauia.

Kennett, D., Anderson, A.J., Prebble, M., Conte, E. and Southon, J. 2006. Prehistoric human impacts on Rapa, French Polynesia. Antiquity 80:1-15

Kennett, D.J. and Kennett, J.P. 2000. Competitive and Cooperative Responses to Climatic Instability in Coastal Southern California. American Antiquity 65:379-395.

Kirch, P.V. 1984. The Evolution of the Polynesian Chiefdoms. Cambridge University Press, Cambridge.

Kirch, P.V. 1986. Rethinking East Polynesian Prehistory. Journal of the Polynesian Society 95:9-40.

Kirch, P.V. and Ellison, J. 1994. Palaeoenvironmental evidence for human colonization of remote Oceanic islands. Antiquity 68:310-321.

Kirch, P.V. and Kahn, J.G. 2007. Advances in Polynesian Prehistory: Assessment of the Past Decade (1993-2004). Journal of Archaeological Research 15:191-238.

Kooijman, S. 1972. Tapa in Polynesia. B.P. Bishop Museum Bulletin 234, Honolulu.

Kuhlken, R. 1999. Warfare and Intensive Agriculture in Fiji. In: Gosden, C. and Hather, J. (eds), The Prehistory of Food: Appetites for Change. Routledge: Taylor and Francis Group, New York.

Ladefoged, T.N. 1993. Evolutionary Process in an Oceanic Chiefdom: Intergroup Aggression and Political Integration in Traditional Rotuman Society. Unpublished PhD Dissertation, University of Hawaii.

Lamb, W.K. (ed), 1984. George Vancouver, A Voyage of Discovery to the North Pacific Ocean and Round the World 1791-1795, Volume I. The Hakluyt Society, London.

McGlone, M.S. and Wilmshurst, J.M. 1999. Dating initial Maori environmental impact in New Zealand Quaternary International 59:5-16.

Mulloy, W. 1965. Report 3: The fortified village of Morongo Uta. In: Heyerdahl, T. and Ferdon, E.W. (eds), Reports of the Norwegian Archaeological Expedition to Easter Island and the East Pacific, Volume 2 Miscellaneous Papers, pp. 23-68. Monographs of the School of American Research and the Kon-Tiki Museum, 24 Pt. 2, Esselte AB, Stockholm.

Naval Intelligence Division 1943. Pacific Islands. Volume II Eastern Pacific. B.R. 519 B (Restricted) Geographical Handbook Series. United States Navy, Washington DC.

Parkes, A. 1998. Environmental change and the impact of Polynesian colonization: sedimentary records from central Polynesia. In: Kirch, P.V. and Hunt, T.L. (eds), Historical Ecology in the Pacific Islands: prehistoric environmental and landscape change, pp. 166-199. Yale University Press, New Haven.

Paulding, H. 1831. Journal of a cruise of the United States Schooner Dolphin, among the islands of the Pacific Ocean etc. G. \& C. \& H. Carvill, New York.

Prebble, M.J. 2005. Islands, Floras and History: an environmental history of plant introductions and extinction on the Austral Islands, French Polynesia. Unpublished PhD dissertation, The Australian National University, Canberra.

Rechtman, R.B. 1992. The Evolution of Sociopolitical Complexity in the Fiji Islands. Unpublished PhD dissertation, University of California, Los Angeles.

Rolett, B.V. and Conte, E. 1995. Renewed investigation of the Haatuatua Dune (Nuku Hiva, Marquesas Islands): a key site in Polynesian prehistory. Journal of the Polynesian Society 104:195-228. 
Routledge, S. and Routledge, K. 1921. Notes on some archaeological remains in the Society and Austral Islands. Journal of the Royal Anthropological Institute of Great Britain and Ireland 51:438-455.

Smith, C.S. 1965a. Report 5: Test excavations and surveys of miscellaneous sites on the island of Rapa Iti. In: Heyerdahl, T. and Ferdon, E.W. (eds), Reports of the Norwegian Archaeological Expedition to Easter Island and the East Pacific, Volume 2 Miscellaneous Papers, pp. 77-87. Monographs of the School of American Research and the Kon-Tiki Museum, 24 Pt. 2, Esselte AB, Stockholm.

Smith, C.S. 1965b. Report 6: The burial complex on the island of Rapa Iti. In: Heyerdahl, T. and Ferdon, E.W. (eds), Reports of the Norwegian Archaeological Expedition to Easter Island and the East Pacific, Volume 2 Miscellaneous Papers, pp. 89-95. Monographs of the School of American Research and the Kon-Tiki Museum, 24 Pt. 2, Esselte AB, Stockholm.

Smith, S.P. 1910. Easter Island (Rapa-Nui) and Rapa (Rapa-Iti) Island. Journal of the Polynesian Society 19:171-175.

Steadman, D., Vargas, P. and Cristino, C. 1994. Stratigraphy, chronology and cultural context of an early faunal assemblage from Easter Island. Asian Perspectives 33:79-96.

Stokes, J.F.G. n.d. Ethnology of Rapa Island. Unpublished draft of B.P. Bishop Museum Bulletin of the Bayard Dominick Expedition. Five unbound volumes with multiple pagination (page numbers used here are generally the circled numbers). B.P. Bishop Museum, Honolulu.

Sutton, D.G. 1987. A paradigmatic shift in Polynesian prehistory: implications for New Zealand. New Zealand Journal of Archaeology 9:135-155.

Sutton, D.G., Furey, L. and Marshall, Y. 2003. The Archaeology of Pouerua. Auckland University Press, Auckland.

Walczak, J. 2001. Le peuplement de la Polynésie orientale. Une tentative d'approche historique par les exemples de Tahiti et de Rapa (Polynésie française). Unpublished PhD dissertation, University of Paris I - Pantheon Sorbonne, Paris.

Walczak, J. 2003. Presentation des données actuelles sur la préhistoire de Rapa Iti (archiple des Australes-Polynésie Française). In: Orliac, C. (ed), Archéologie en océanie insulaire: peuplement, sociétés et paysages, pp. 28-45. Editions Artcom, Paris.

Wilmshurst, J.M., Hunt, T.L., Lipo, C.P. and Anderson, A.J. 2011. High-precision radiocarbon dating shows recent and rapid initial human colonization of East Polynesia. Proceedings of the National Academy of Sciences 108(5):1815-20. 